\title{
"Salt lick potentials in Ecotourism Management of Borgu Sector": Kainji Lake National Park, Nigeria
}

\author{
Wahab, M.K.A ${ }^{1 *}$; Alarape, A. A. ${ }^{2}$; Halidu, S. K. ${ }^{3}$; and Idowu, I. A. ${ }^{1}$ \\ ${ }^{1}$ Department of Fisheries and Wildlife Management, Osun State University, Osogbo, Nigeria. \\ ${ }^{2}$ Department of Wildlife and Ecotourism Management, University of Ibadan, Nigeria. \\ ${ }^{3}$ Department of Wildlife and Ecotourism Management, Federal College of Wildlife Management, New - Bussa, Nigeria
}

\begin{abstract}
Ecotourism is a form of tourism undertaken to view and / or encounter wildlife in a range of settings. One of such eco-destinations in which wildlife can be viewed is salt licks. The study was undertaken at Borgu sector of Kainji Lake National Park. Data collection was carried out using systematic random sampling for the selection of salt lick sites, direct and indirect fauna observation using transect lines to determine the level of site utilization.

Secondary data from the park management and laboratory analysis of salt lick, soil samples to detect the mineral compositions and richness of the licks as relevant to ecotourism activities in the park was examined. Observation revealed that the iron concentration (a trace element) is high in salt lick 1 (332.33), while the lowest was recorded in salt lick 6 (36.36).It was also revealed that the content of calcium (a major element) is high in salt lick 1 (4.22), with the least recorded in salt lick 6 (0.40). It was perceived that salt lick 3 and 4 were least utilized during the dry seasons.

It is important to know that the mineral content of salt lick sites can be a factor affecting its utilization by fauna resources. It was observed that, turn-out of tourists visiting the park fluctuates; as a result of anthropogenic activities and other limiting factors. The overall benefits derived from salt licks for wildlife health, majorly through herbivores are crucial in maintaining a healthy wildlife community for their reproduction and survival.

Keywords-Conservation, Biodiversity Management, Ecotourism potential, Management tool, Eco-destination.
\end{abstract}

\section{INTRODUCTION}

Development of ecotourism management had long been recognized since the period of independence when the National Policies on wildlife management was established in the country. The establishment of protected areas for conservation management basically centers on protection and conservation of sites for National development. In recent times, the National wildlife policy now centers equal emphasis on all aspects of wildlife utilization; recreation, tourism, bush meat production and preservation of gene pool. The dire need to manage wildlife for tourism development was placed first among other goals in many states of the federation, due to immense benefits derivable from tourism; revenue generation, foreign exchange, value addition to the local product and job creation. Tourismoffers about 1 million jobs in California State of America (Odumosu 2003 as cited by Ijeomah 2007) as well as 200,000 jobs in Sri lanka (Ashley, 2005).Tourism is as well identified as one of the key areas by the Nigerian governmentfor the nation's socioeconomic transformation (Ijeomah, 2007). The transformation can be maximized throughproper evaluation of tourism performance in eco-destinations as an effective tool on which ecotourism management of a National park can be based.Tourism and conservation objectives are complementary and jointly achievable in National Parks and game reserves, although tourism is supposed to be secondary to conservation as described by the proponents of ecological tourism (Yunis, 2003. On this basis, Nigeria National Parks alongside its major mandate to conserve flora and fauna in various ecological zones are also scheduled to act as catalysts for the development of ecotourism (NTDC, 2005).Wildlife tourism often referred to as ecotourism is a form of tourism undertaken to view and / or encounter wildlife in a range of settings, from capture semi captive, to in the wild and it encompasses a variety of interactions from passive observation to feeding and /or touching the species viewed 
(Newsome et al, 2005).One of such eco-destinations in which wildlife can be viewed is salt licks. Salt licks are key places and locations for the ecological dynamics of wildlife communities in protected areas. It is a natural mineral deposit area where animals visit frequently and actively for mineral uptake through licking or geophagy.Geophagy is a behavioral patterncommon among ruminants for addressing mineral deficiencies, deficiencies in major and trace elements which may aid to ease digestiveproblems or buffer the effects of dietary toxins (Stephens on et al. 2011). The location of a mineral lick in a protected area strongly influence the movement and distribution of ungulate populations (Heimer 1974; Simmons 1982; Watts and Schemnitz, 1985). Unlike forage vegetation patterns, which are non-static and vary with natural disturbance and weather over time, mineral licks are a static resource that may be used by many generations of a population.Species composition of visitors and frequency of visits may differ from one lick to the next (Tobler 2009; Blake 2010), such variation may reflect differences in mineral composition of the soil among different sites (Abrahams et al. 1999) predation may affect the types of species and numbers of visits to different licks (Izawa et al. 1993) or differences among species in habitat preferences and availability of licks in different habitats.Kainji Lake National Park is an area of high biodiversity value and includes a number of saltlick sites frequently used by different herbivores and carnivores. However the ungulate species are prone to flee when exposed to human disturbance(Stankowich 2008). These small, localized areas areimportant resources for all ungulate species; their preservation on the landscape is vitalin conservation management approaches (Dormaar and Walker 1996; Rea et al. 2004).

\section{MATERIALS AND METHOD}

Kainji Lake National Park is Nigeria's first experiment at establishing and managing a National park. The National park was established in 1979 (under decrees 46 of 29th July, 1979)making it one of the most important National parks in Africa, it is highly endowed with many flora and fauna resources. The park is located between latitudes $9^{\circ} 40^{\prime} \mathrm{N}$ to $10^{\circ} 30^{\prime} \mathrm{N}$ and longitudes $4^{\circ} 30^{\prime} \mathrm{E}$ to $5^{\circ} 50^{\prime} \mathrm{E}$. It is made up of two non-contiguous sectors, the Borgu and Zugurma sectors with Borgu sector comprising 3,970.83 km2 (74.3\%) and the Zugurma sector covering an area of $1,370 \mathrm{~km} 2(25.7 \%)$. The savanna climate of the park is responsible for the distinct wet and dry seasons. The six main broad vegetationclassifications in the Park are;

(i) Burkea Africana /Deuteriummicrocarpus woodland savanna

(ii) Diospyrusmespiliformisdry forest

(iii) Riparian forest and woodland

(iv) Terminaliamacropteratree savanna

(v) Isoberliniatomentosawoodland and

(vi) Isoberliniadoka, savanna woodland.

The mean temperature observed during the wet season is about $30^{\circ} \mathrm{C}$ which drops to $28^{\circ} \mathrm{C}$ during the dry season associated with the north easternharmattan winds. Rainfall is a major climatic element in the park facilitating vegetation growth and the hydrology of the rivers. The mean annuals rainfall is about $1200 \mathrm{~mm}$.

III. RESULTS

Table 1: Mineral analysis of nine soil samples

\begin{tabular}{llllllll}
\hline $\begin{array}{l}\text { Sample } \\
\text { No }\end{array}$ & Sample ID & $\begin{array}{l}\mathrm{Cu}+ \\
(\mathrm{mg} / \mathrm{L})\end{array}$ & $\begin{array}{l}\mathrm{Mg} 2+ \\
(\mathrm{mg} / \mathrm{L})\end{array}$ & $\begin{array}{l}\mathrm{Mn} 2+ \\
(\mathrm{mg} / \mathrm{L})\end{array}$ & $\begin{array}{l}\mathrm{Fe} 2+ \\
(\mathrm{mg} / \mathrm{L})\end{array}$ & $\begin{array}{l}\mathrm{Zn} 2+ \\
(\mathrm{mg} / \mathrm{L})\end{array}$ & $\begin{array}{l}\mathrm{Ca} 2+ \\
(\mathrm{mg} / \mathrm{L})\end{array}$ \\
\hline 1 & Salt lick 1 & 0.37 & 7.69 & 2.24 & 332.33 & 1.398 & 4.22 \\
2 & Salt lick 2 & 0.26 & 5.58 & 1.172 & 257.03 & 1.20 & 2.49 \\
3 & Salt lick 3 & 0.15 & 2.96 & 0.70 & 99.92 & 1.267 & 0.58 \\
4 & Salt lick 4 & 0.37 & 5.91 & 1.17 & 737.50 & 0.941 & 1.28 \\
5 & Salt lick 5 & 0.20 & 1.95 & 1.53 & 155.37 & 0.74 & 1.28 \\
6 & Salt lick 6 & 0.09 & 2.05 & N.D & 36.36 & 0.68 & 0.47 \\
7 & Salt lick 7 & 0.26 & 5.97 & 1.054 & 298.16 & 0.68 & 1.56 \\
8 & Salt lick 8 & 0.20 & 3.46 & 1.17 & 148.20 & 0.68 & 9.20 \\
9 & Salt lick 9 & 0.37 & 7.095 & 0.94 & 298.16 & N.D & 1.28 \\
\hline
\end{tabular}

Note: N.D- Not Detected. 
Reconnaissance survey of the park (Borgu sector) was carried out to familiarize with the park resources and salt licks present which can function as a tool in enhancing ecotourism development in the protected area. Soil samples were collected from nine different salt lick points randomly selected from the total of twenty five salt licks in the Borgu sector of the park. These samples were analyzed in Osun state college of Agriculture's laboratory using Atomic Absorption Spectrophotometer (AAS) Model PG 990 to detect the various mineral compositions. The soil samples were digested using concentrated Nitric acid, $1 \mathrm{~g}$ weighed into a digestion flask, and $10 \mathrm{ml}$ of Acid added. The mixture was heated at $200^{\circ} \mathrm{C}$ for one hour to breakdown the elements composition.

Secondary data was gathered to elicit information from the park management on tourist's visitation in the park for the year 2007-2017. These data were subjected to descriptive analys is involving the use of charts, graphs and tables.

\section{Concentration of Major Elements in the Sampled Soils}

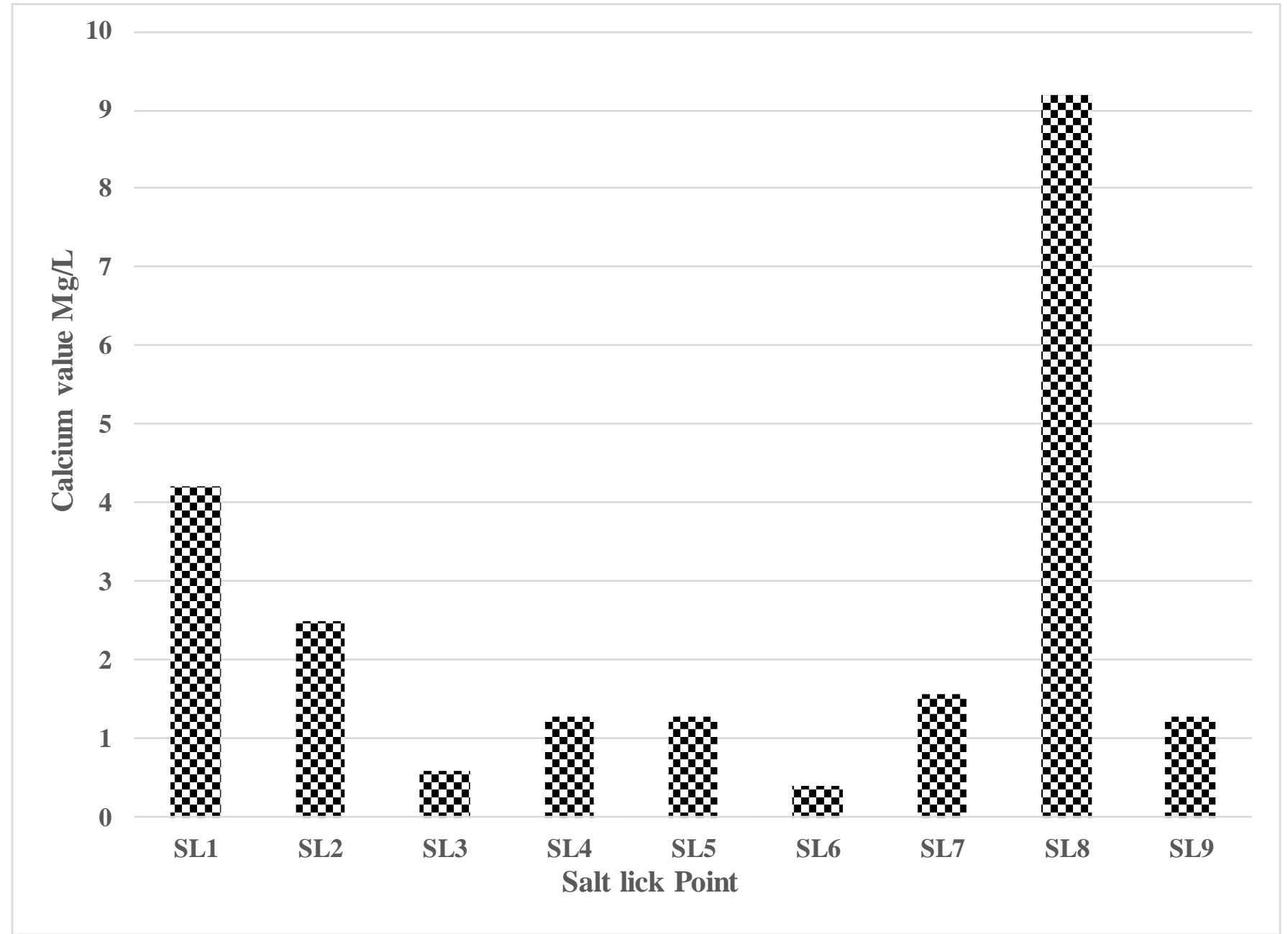

Fig.1: Calcium value $\left(\mathrm{Ca}^{2+}\right)$ of the soil samples across all saltlick sites 


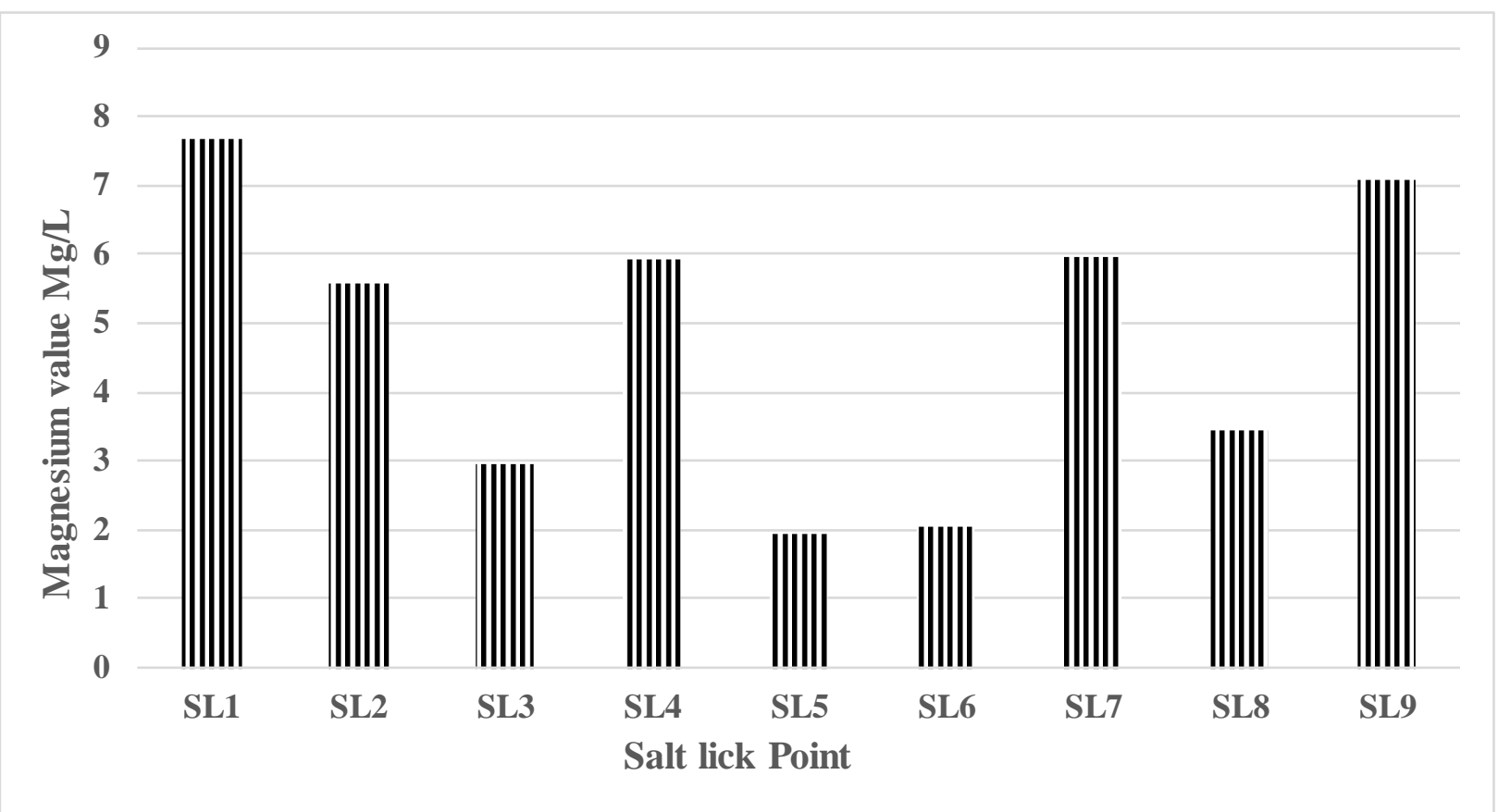

Fig.2: Magnesium value $\left(\mathrm{Mg}^{2+}\right)$ of the soil samples across all saltlick sites.

Concentration of Trace Hements in the Sampled Soils

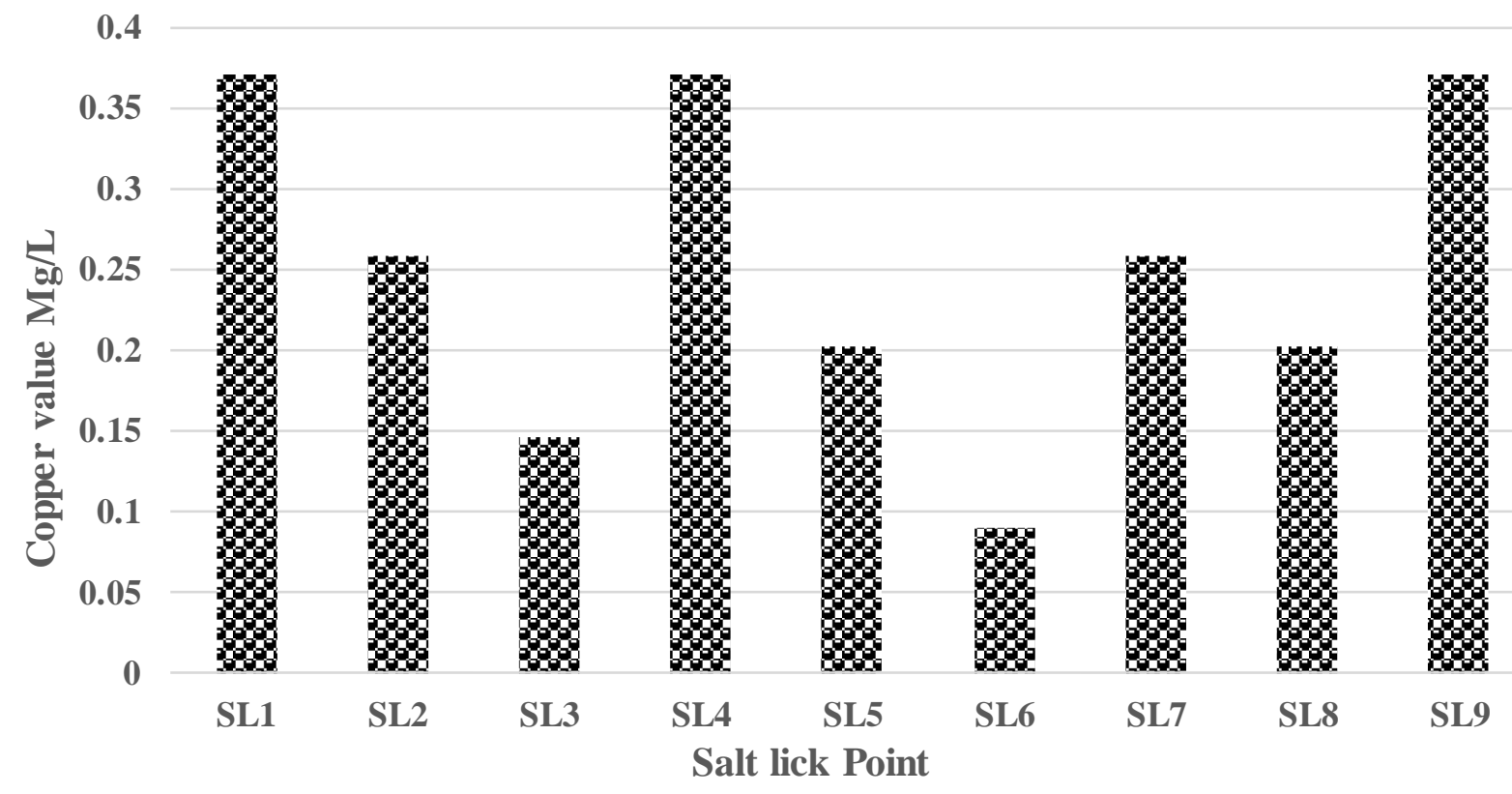

Fig.3: Copper value $\left(\mathrm{Cu}^{3+}\right)$ of the soil samples across all saltlick sites. 


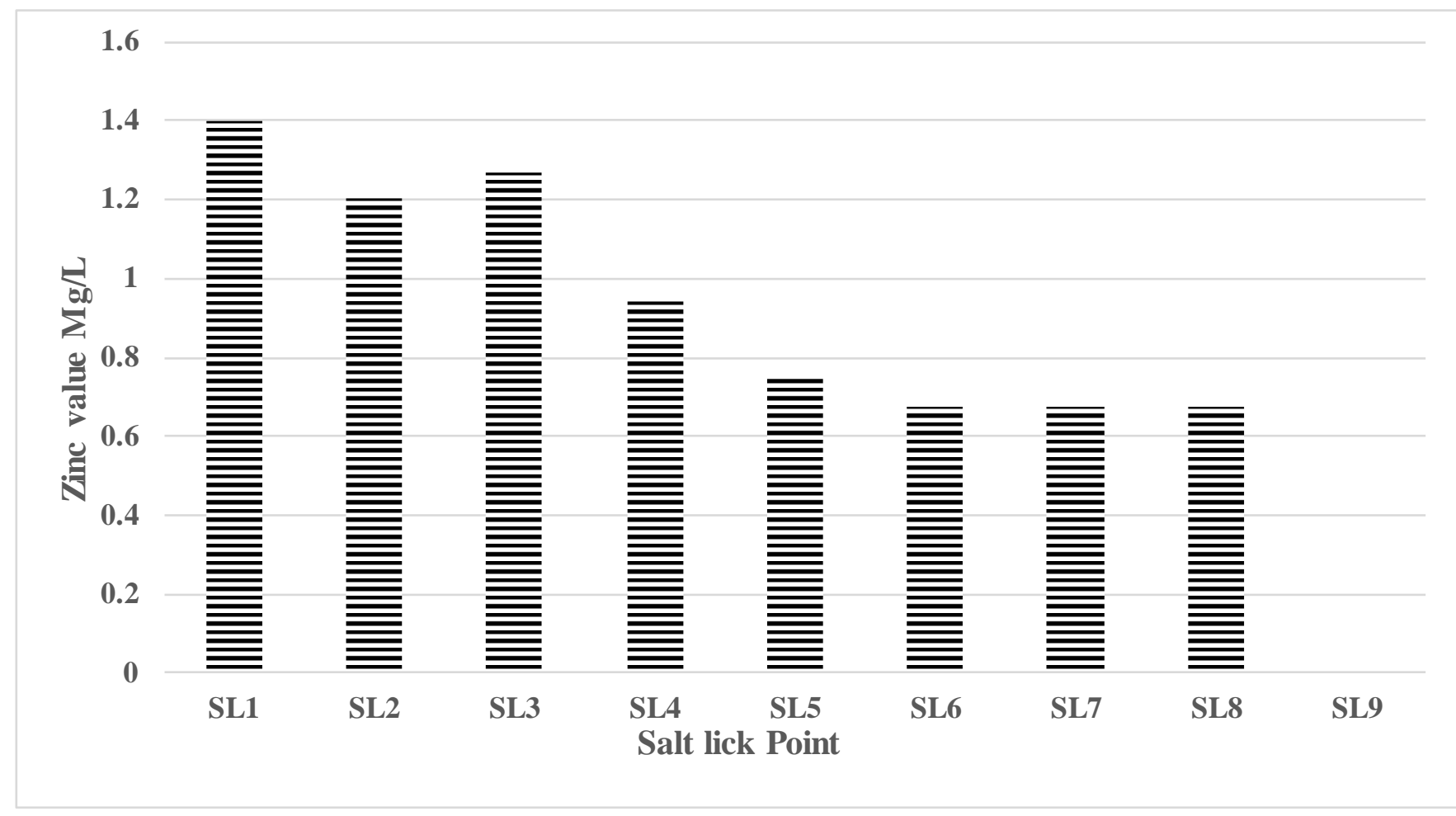

Fig.4: Zinc value $\left(\mathrm{Zn}^{2+}\right)$ of the soil samples across all saltlick sites.

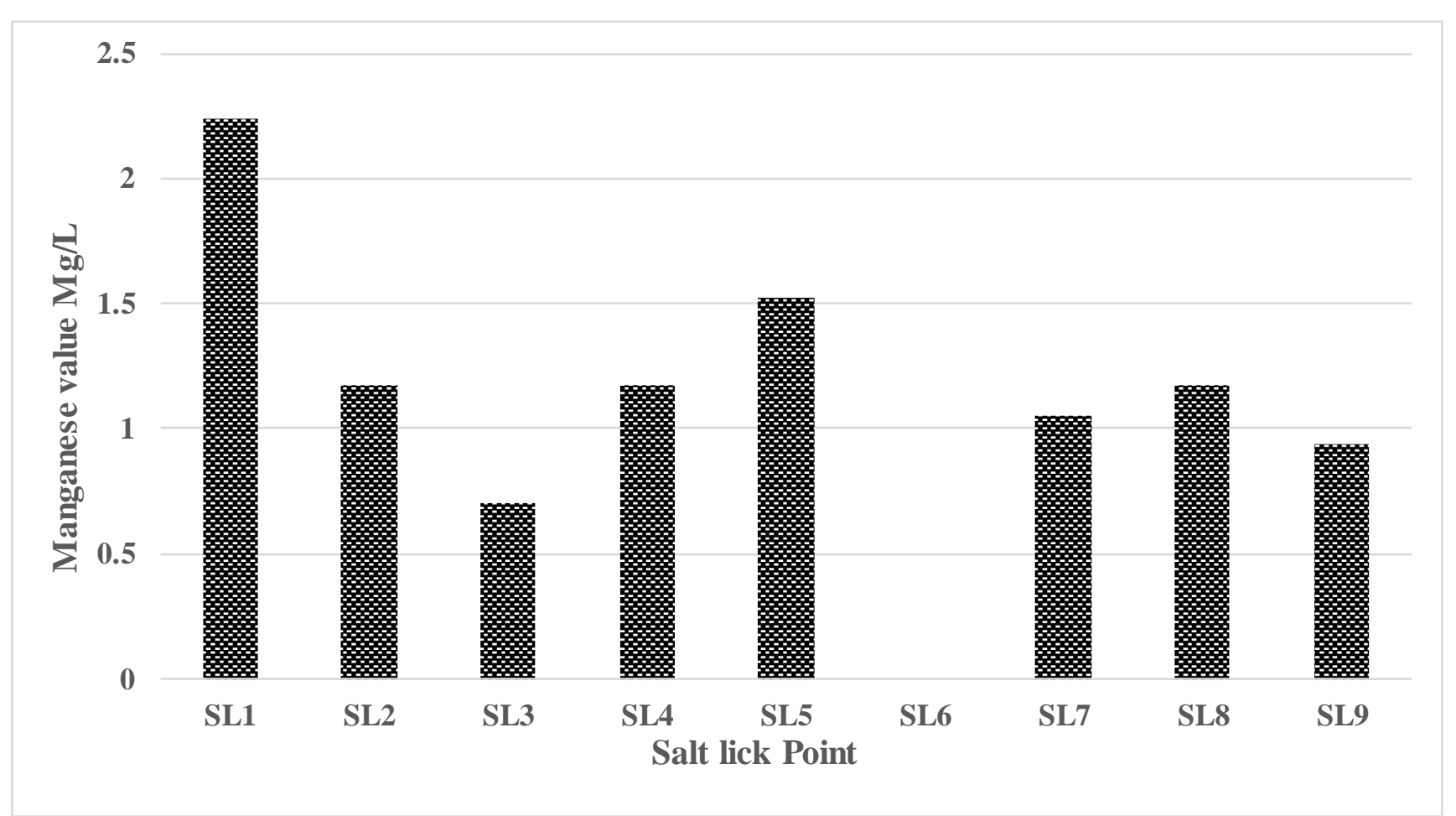

Fig.5: Manganese value $\left(\mathrm{Mg}^{2+}\right)$ of the soil samples across all saltlick sites. 


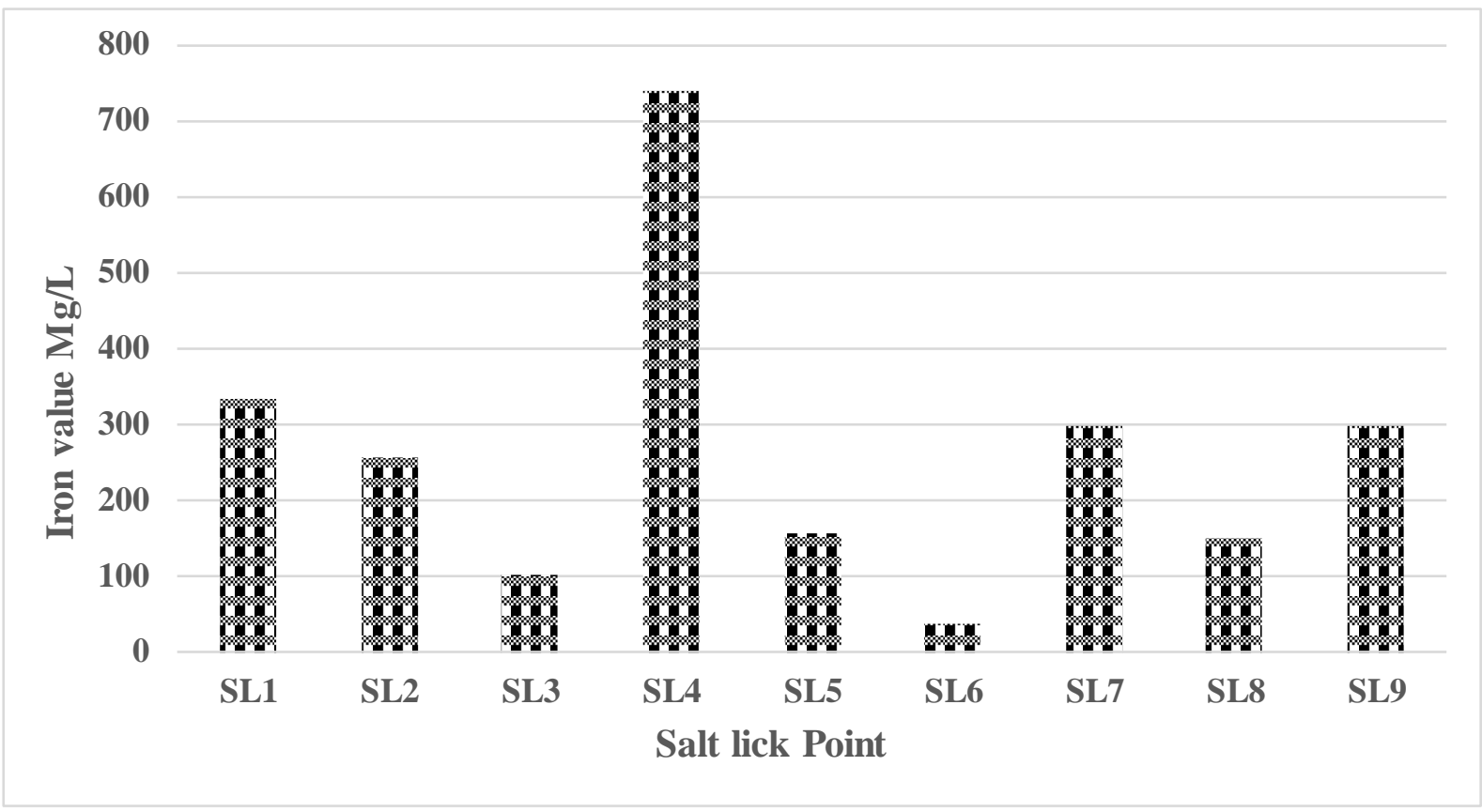

Fig.6: Iron value $\left(\mathrm{Fe}^{2+}\right)$ of the soil samples across all saltlick sites.

Table 2: Level of Utilization of sampled salt lick sites.

\begin{tabular}{lll}
\hline Saltlick Point & Wet season & Dry season \\
\hline SL1 & $\mathrm{Xxx}$ & $\mathrm{Xx}$ \\
SL2 & $\mathrm{Xxx}$ & $\mathrm{Xxx}$ \\
SL3 & $\mathrm{Xxx}$ & $\mathrm{X}$ \\
SL4 & $\mathrm{Xxx}$ & $\mathrm{X}$ \\
SL5 & $\mathrm{Xxx}$ & $\mathrm{Xx}$ \\
SL6 & $\mathrm{Xxx}$ & $\mathrm{Xx}$ \\
SL7 & $\mathrm{Xxxx}$ & $\mathrm{Xxx}$ \\
SL8 & $\mathrm{Xxxx}$ & $\mathrm{Xxx}$ \\
SL9 & $\mathrm{Xxx}$ & $\mathrm{Xxx}$ \\
\hline
\end{tabular}

KEY: $\mathrm{XXXX}=$ Very high, $\mathrm{XXX}=$ High, $\mathrm{XX}=$ Moderate $\mathrm{X}=\mathrm{Low}, \mathrm{SL}=$ Salt Lick.

Table 3: Tourists' influx in Kainji Lake National Park for the year 2007-2017.

\begin{tabular}{lllll}
\hline S/N & Year & Nigerians (Domestic) & Foreigners (International) & Total \\
\hline 1 & 2007 & 4794 & 43 & 4837 \\
2 & 2008 & 4025 & 67 & 4092 \\
3 & 2009 & 4852 & 25 & 4811 \\
4 & 2010 & 6054 & 49 & 6103 \\
5 & 2011 & 4677 & 16 & 4693 \\
6 & 2012 & 3422 & 07 & 3429 \\
7 & 2013 & 7725 & 05 & 7730 \\
8 & 2014 & 929 & - & 929 \\
9 & 2015 & 3066 & 10 & 3076 \\
10 & 2016 & 2993 & 05 & 2998 \\
11 & 2017 & 192 & - & 192 \\
\hline
\end{tabular}




\section{DISCUSSION}

The important role mineral elements play in the nutrition of wild games cannot be overemphasized as much as the trace minerals required for supplementing their diet. Enzymes are activated by trace elements known as metallo-enzymes. The trace elements are required in minute quantity in animal's diet. The ingestion and assimilation of minerals that are not balanced, nutrient deficient or excessively high in a particular mineral element induce changes in the activities, function or concentration of such element in the body tis sue/fluid.

The summary of the mineral content in all the sampled salt lick sites are presented in Table 1. It was observed that the amount of copper found in salt lick 1, 4 and 9 is relatively high $0.37,0.37$ and 0.37 respectivelywhile salt lick 6 has the lowest copper content 0.090 as presented in Figure 3. Observation revealed that the amount of magnesium is high in salt lick 1 (7.69), while the lowest amount is found in salt lick 5 (1.97), as presented in figure 2. Manganese was also found to be high in salt lick 1 (2.24), while the lowest was recorded in salt lick $3(0.70)$ however the content in salt lick 6 was not detected as presented in figure 5. Iron concentration is high in salt lick 1 (332.33), while the lowest was recorded in salt lick 6 (36.36) as presented in Figure 6. Zinc has the highest content in salt lick 1 (1.41), and the leastamount was recorded in salt lick 6, 7 and 8 respectively while no mineral content was detectedin salt lick 9, as presented in Figure 4. The content of calcium is highest in salt lick 1 (4.22), with the least recorded in salt lick $6(0.39)$ as shown in Figure 1.Observation revealed that the level of utilization of salt licks corresponds to the availability of mineral deposits during both seasons of the year. The calcium concentration was high in salt lick 8, which yielded a high level of utilization while salt lick 3 and 4 were least utilized during the dry seasons. This could summarize the fact that Copper, Iron and Zinc (Trace elements) are not readily released for consumption without an external force of rain. The mineral content of salt lick sites can be a limiting factor to its utilization by fauna resources which has overall effect on wildlife viewing at such sites.During the study, it was observed that, turn-out of tourists visiting the park fluctuates year by year as presented in Table 3. This could be associated to the insecurity status of the country, economic melt-down and the operatingseasons of the park. However, tourists' visitation to salt lick sites and ecological sites is impaired due to a number of reasons as identified during the study. The anthropogenic activities of park intruders is experiencing a rapid increase which can be attributed to decline in fauna population within the sites and in the park at large. This has affected the ecotourism activities of the park to eco-destinations that attract large wildlife populace. Above all, the benefitsderived from salt licks for wildlife health, majorly herbivores are crucial in maintaining a healthy wildlife community for reproduction and survival.

\section{CONCLUSION}

Salt licks are key places and locations for the ecological dynamics of wildlife communities in protected areas. Salt lickis a natural mineral deposit area where animals visit frequently and actively for mineral uptake through licking.Ecotourism is a special type of wildlife viewing which centers more on a diverse range of fauna species utilizing this site of great potential.The findings showed that facilities and promotion on salt licks are lacking in Nigeriawhich indicates poor conservation of this natural landscape. Salt licks in remote natural areas need to be sustained to protect them against human activities of vegetation loss and species decline. It is evident that interest to visit salt licks is behind the satisfactory level due to the underutilized ecotourism resources of the park. Management of these resources needs sound and effective monitoring as well as evaluation of the fauna resources to sustain the ecological sites. Awareness on the importance of salt licks for ecotourism development need to be enhanced by the park management so as to combat the negative use of these sites for better sustainable conservation measures.

\section{REFERENCES}

[1] Abrahams PW (1999)The chemistry and mineralogy of three savannas lick soils.J. Chem. Ecol., 25:2215-2228.

[2] Ashley C (2003)Theindian ocean tsunami and tourism.Overseas development institute. www.odi.org.uk/publications/opinion.

[3] Blake JG, Guerra J, Mosquera D, Torres R, Loiselle BA, RomoD (2010) Use of mineral licks by white-bellied spider monkeys (Atelesbelzebuth) and red howler monkeys (Alouattaseniculus) in eastern Ecuador. Int. J. Primatol.31: 471-483.

[4] Dormaar, JF, Walker BD (1996) Elemental content of animal licks along the eastern slopes of the Rocky Mountains in southern Alberta, Canada. Canadian Journal of Soil Science 76: 509-512.

[5] Heimer WE(1974)The importance of mineral licks to Dall sheep in interior Alaska and its significance to sheep management: Proceedings of the Third Biennial Wild Sheep and Goat Council Conference 3: 49-63.

[6] Izawa K(1993)Soil-eating by Alouatta and Ateles. Int. J. Primatol., 14: 229-242. 
[7] Rea RV,Hodder DP, Child KN(2004) Considerations for natural mineral licks used by moose in land use planning and development. Alces 40: 161-167.

[8] Simmons NM(1982) Seasonal ranges of Dall's sheep, Mackenzie Mountains, Northwest Territories. Arctic 35: 512-518.

[9] Stankowich T (2008) Ungulate flight responses to human disturbance: a review and meta-analysis. Biological Conservation 141: 2159-2173.

[10] Tobler MW,Carrillo-Percastegui SE, Powell G (2009) Habitat use, activity patterns and use of mineral licks by five species of ungulate in south-eastern Peru.J. Trop. Ecol. 25:261-270.

[11] Watts TJ, SchemnitzSD(1985) Mineral lick use and movement in a remnant desert bighorn sheep population. Jour. of Wildlife Mgt. 49: 994-996.

[12] Ijeomah HM, Alarape AA,Ogogo AU(2007) Management ethics and strategies towards sustainable tourism development in Jos Wildlife Park. Jour.of Environ.Extens.6:100106http://www.ajol.info.

[13] NTDC (2005) Nigeria: Beauty in diversity. Nigerian Tourism Development Corporation. Abuja.

[14] Newsome D, Dowling R, Moore S (2005) Wildlife tourism channel view publication clevendon U.K. of foreign investment. "Hum. Ecol., 33(2): 217-244.

[15] Stephenson J D, Mills A, Eksteen, J. J., Milewski, AV, Myburgh JG (2011) Geochemistry of mineral licks at Loskop Dam Nature Reserve, Mpumalanga, South Africa. Environmental Geochemistry and Health, 33: 49-53.

[16] Yinus E (2003)Sustainable tourism and poverty alleviation, World Tourism Organization, Spain, Pp.1-4. http://www.world-tourism.org. 